\title{
Uji Aktivitas Antibakteri Ekstrak Etanol Bawang Dayak (Eleutherine palmifolia (L.) Merr) terhadap Bakteri Staphylococcus aureus
}

\section{Antibacterial Activity of Ethanolic Extract of Eleutherine palmifolia (L.) Merr against Bacteria Staphylococcus aureus}

\author{
Warsiti*, Sisca Dwi Kusuma Wardani, Ardea Achmad Ramadhan, Ratna Yuliani \\ Fakultas Farmasi, Universitas Muhammadiyah Surakarta, Jl. A. Yani Tromol Pos 1, Pabelan, Surakarta, \\ Indonesia \\ *E-mail: sitiwar388@gmail.com
}

\begin{abstract}
Abstrak
Staphylococcus aureus merupakan bakteri penyebab infeksi yang disertai nanah karena terjadi kerusakan jaringan. Penyakit infeksi yang disebabkan oleh $S$. aureus antara lain infeksi luka, bisul, jerawat, dan impetigo. Bawang dayak memiliki manfaat sebagai antibakteri. Penelitian ini bertujuan untuk mengetahui ekstrak etanol bawang dayak mempunyai aktivitas antibakteri terhadap Staphylococcus aureus. Metode yang digunakan adalah difusi disk. Hasil identifikasi bakteri dengan pengecatan Gram menunjukkan bakeri termasuk golongan Gram positif dan dengan uji manitol bakteri dapat memfermentasi manitol. Uji sensitivitas bakteri menggunakan tiga antibiotik yaitu sefoksitin $30 \mu \mathrm{g}$, vankomisin $30 \mu \mathrm{g}$, dan linezolid $30 \mu \mathrm{g}$. Staphylococcus aureus bersifat sensitif terhadap ketiga antibiotik. Besar masing-masing zona hambat 23,5 mm; $17 \mathrm{~mm}$ dan $27,5 \mathrm{~mm}$. Antibiotik yang digunakan sebagai kontrol positif uji aktivitas antibakteri adalah vankomisin $30 \mu \mathrm{g}$ dihasilkan diameter zona hambat rata-rata 17,83 $\pm 2,25 \mathrm{~mm}$. Sedangkan kontrol pelarut DMSO (Dimetil sulfoksida) tidak menghasilkan zona hambat. Seri konsentrasi ekstrak etanol bawang dayak yaitu 25\%; 50\%; $75 \%$ dan $100 \%$. Uji aktivitas antibakteri ekstrak bawang dayak didapatkan rata-rata diameter zona hambat $8,17 \pm 0,29 \mathrm{~mm} ; 10,67 \pm 1,44 \mathrm{~mm} ; 10,33 \pm 1,53 \mathrm{~mm}$; dan 12,33 $\pm 1,61 \mathrm{~mm}$.
\end{abstract}

Kata kunci: difusi disk, ekstrak etanol bawang dayak , Staphylococcus aureus

\begin{abstract}
Staphylococcus aureus is an infectious bacteria with pus because of tissue damage. Infectious diseases caused by $S$. aureus include wound infections, ulcers, pimples, and impetigo. Dayak onions have the benefit of being antibacterial. This research aims to study the antibacterial activity of ethanolic extract of Dayak onions against Staphylococcus aureus. The antibacterial study was carried out using the disk diffusion method. Identification of bacteria by Gram staining showed Gram-positive bacteria which can ferment mannitol with the mannitol test. A bacterial sensitivity test was conducted using three antibiotics i.e. cefoxitin 30 $\mu$,

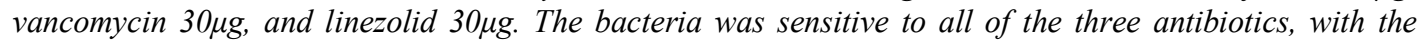
inhibitory zone of $23.5 \mathrm{~mm} ; 17 \mathrm{~mm}$ and $27.5 \mathrm{~mm}$, respectively. Vancomycin $30 \mu \mathrm{g}$ was used as a positive control, resulted in average diameter of the inhibitory zone of $17.83 \pm 2.25 \mathrm{~mm}$, whereas a control solvent DMSO (Dimethyl sulphoxide) did not produce zones. The ethanolic extract of Dayak onion in the concentration of $25 \% ; 50 \%$; $75 \%$ and $100 \%$ showed the average diameter of inhibitory zones of $8.17 \pm 0.29$ $\mathrm{mm} ; 10.67 \pm 1.44 \mathrm{~mm} ; 10.33 \pm 1.53 \mathrm{~mm}$; and $12.33 \pm 1.61 \mathrm{~mm}$, respectively.
\end{abstract}

Keywords: disk diffusion, ethanolic extract of Dayak onions, Staphylococcus aureus

\section{PENDAHULUAN}

Staphylococcus aureus merupakan bakteri penyebab infeksi yang disertai nanah karena terjadi kerusakan jaringan. Penyakit infeksi yang disebabkan oleh $S$. aureus antara lain infeksi luka, bisul, jerawat, dan impetigo. Infeksi yang lebih berat juga dapat terjadi diantaranya pneumonia, infeksi saluran kemih, mastitis, meningitis, endokarditis dan penyebab utama infeksi nosokomial (Ryan, et al., 1994).

Hampir setiap orang mengalami infeksi S.aureus dan sekitar $30 \%$ orang memiliki bakteri jenis ini di hidungnya. Keberadaaan S.aureus pada saluran pernafasan atas dan kulit tidaklah menyebabkan bahaya apapun, hanya saja bakteri S.aureus ini bisa menyebabkan derajat kerapuhan yang 
beragam, dari keracunan makanan, hingga infeksi kulit ringan dan infeksi serius atau fatal yang mengancam jiwa. Beberapa kondisi patologi yang disebabkan oleh S.aureus adalah bisul, jerawat, impetigo dan infeksi luka. Adapun infeksi luka yang lebih berat diantaranya pneumonia, mastitis, phlebitis, meningitis, infeksi saluran kemih, endocarditis dan sindroma syok toksik (Kusuma, 2009).

Pada mulanya bawang dayak merupakan tanaman liar yang tumbuh di hutan, dan sama sekali tidak dimanfaatkan, bentuknya yang berbeda dengan bawang merah (Allium ascalonicum L.) membuat masyarakat Kalimantan tidak menggunakannya. Selain itu bawang dayak hanya dianggap sebagai rumput liar. Namun, dengan berjalannya waktu, bawang dayak dikembangkan oleh suku Dayak sehingga semakin dicari dan dimanfaatkan, salah satunya sebagai obat kanker karena bawang dayak memiliki antioksidan tinggi (Hidayah, 2015). Selain itu ternyata bawang dayak memiliki aktivitas antibakteri.

Dalam umbi bawang dayak terkandung senyawa fitokimia yaitu alkaloid, glikosida, flavonoid, fenolik, steroid, dan tanin yang merupakan sumber obat sehingga berpotensi untuk dikembangkan sebagai tanaman obat modern dalam kehidupan manusia (Galingging, 2009). Ekstrak bawang dayak mengandung alkaloid, saponin, tannin, fenolik, dan triterpenoid sedangkan ekstrak etanol bawang dayak mengandung alkaloid, saponin, tannin, fenolik, flavonoid, dan triterpenoid (Febrinda, 2013). Bawang dayak memiliki banyak manfaat yaitu sebagai antibakteri, antioksidan, antiradang, menghentikan pendarahan dan antitumor (Alves et al., 2003).

Ekstrak bawang dayak (Eleutherine palmifolia (L.) Merr) telah diuji aktivitas antibakteri terhadap Staphylococcus aureus. Dari hasil penelitian sebelumnya didapatkan adanya daya hambat antibakteri ekstrak etanol bawang dayak terhadap pertumbuhan bakteri Staphylococcus aureus. Daya hambat ditunjukkan dengan terbentuknya zona bening di sekitar disk pada konsentrasi 25\%, 50\%, $75 \%, 100 \%$ dengan rata-rata diameter zona hambat berturut-turut sebesar 18,32;18,58 $\mathrm{mm} ; 19,47 \mathrm{~mm}$; dan 20,58 mm (Giardani, 2017). Semakin besar konsentrasi ekstrak maka semakin besar diameter zona hambatnya.

Pada penelitian ini dilakukan uji aktivitas antibakteri ekstrak etanol bawang dayak terhadap bakteri Staphylococcus aureus. Penelitian ini dilakukan untuk membandingkan aktivitas antibakteri ekstrak etanol bawang dayak terhadap Staphylococcus aureus berdasarkan bentuk bawang dayak yang digunakan. Penelitian sebelumnya menggunakan bawang dayak segar sedangkan penelitian ini menggunakan serbuk bawang dayak yang diperoleh dari distributor. Ekstrak etanol bawang dayak diharapkan memiliki aktivitas antibakteri terhadap Staphylococcus aureus yang sama dengan penelitian sebelumnya. Apabila terbukti memiliki aktivitas antibakteri, maka ekstrak ini dapat dikembangkan menjadi antibakteri baru yang berasal dari bahan alam mengingat bahwa banyak antibiotik yang tersedia tidak poten terhadap Staphylococcus aureus.

\section{METODE PENELITIAN}

\section{Alat}

Alat yang digunakan dalam penelitian adalah rotary evaporator, timbangan analitik, cawan petri, pipet tetes, cawan porselen, batang pengaduk, jarum ose lurus, jarum ose bulat, tabung reaksi, spreader, mikropipet, penggaris, waterbath, inkubator, inkubator shaker, gelas objek, gelas penutup, mikroskop.

\section{Bahan}

Bahan yang digunakan dalam penelitian adalah serbuk bawang dayak, bakteri Staphylococcus aureus, media Mueller Hinton (MH) padat, media Manitol Salt Agar (MSA), media Brain Heart Infusion (BHI) cair, disk cakram kosong, disk cakram antibiotik sefoksitin, linezolid, vankomisin, 
white tips, yellow tips, blue tips, cat Gram A, $\mathrm{B}, \mathrm{C}, \mathrm{D}$, minyak imersi, formalin 1\%, DMSO. Pembuatan Ekstrak Etanol Bawang Dayak

Sejumlah $100 \mathrm{~g}$ serbuk bawang dayak diekstraksi dengan metode maserasi. Pelarut yang digunakan pelarut etanol $96 \%$ dengan volume 5 kali berat sampel. Hasil ekstrak dipekatkan dengan rotary evaporator dan waterbath hingga diperoleh ekstrak yang kental.

\section{Pembuatan Suspensi Bakteri Staphylococcus aureus}

Kultur bakteri diambil dengan jarum ose bulat, digoreskan pada media $\mathrm{MH}$ dan diinkubasi selama 24 jam. Setelah diinkubasi selama 24 jam diambil satu koloni bakteri kemudian di masukkan ke dalam $5 \mathrm{~mL}$ media BHI cair. Dishaker selama 2 jam agar bakteri tercampur merata dalam media, selanjutkan di tambahkan $\mathrm{NaCl} 0,9 \%$ hingga konsentrasi bakteri $0,5 \times 10^{8} \mathrm{CFU}$ per $\mathrm{mL}$ (dibandingkan dengan Mc Farland 0,5).

\section{Pengecatan Gram}

Koloni bakteri diambil dengan jarum ose bulat, digoreskan pada gelas objek setipis mungkin. Dipanaskan gelas objek di atas Bunsen sampai preparat kering. Kemudian ditetesi dengan formalin 1\%. Digenangi preparat dengan cat Gram A (Kristal violet, alkohol $96 \%$, ammonium oksalat $1 \%$ dalam akuades) selama 3 menit. Dibuang cat tanpa dicuci dengan air, digenanggi preparat dengan cat Gram B (iodium, kalium iodida, akuades) selama 1 menit. Dibuang cat Gram B dengan air, ditetesi cat Gram C (aseton, alkohol) sampai warna cat hilang. Digenangi preparat dengan cat Gram D (safranin, alcohol 96\%, akuades) selama 2 menit. Preparat dicuci dan dikeringkan pada suhu kamar posisi miring. Setelah kering ditetesi minyak imersi dan ditutup dengan gelas penutup kemudian diamati dibawah mikroskop dengan perbesaran 1000 kali.

\section{Uji Identifikasi Manitol}

Kultur bakteri diambil dengan jarum ose lurus. Kemudian ditusukkan pada bagian tegak dan digoreskan dengan pola zig-zag pada bagian miring media MSA. Lalu diinkubasi selama 24 jam pada suhu $37^{\circ} \mathrm{C}$. Setelah inkubasi 24 jam diamati warna media pada bagian tegak dan miring.

\section{Uji Sensitivitas Bakteri Staphylococcus} aureus

Uji sensitivitas menggunakan vankomisin, sefoksitin, dan linezolid dengan metode difusi disk terhadap Staphylococcus aureus. Disk antibiotik ditempelkan pada media MH padat yang telah diinokulasi bakteri Staphylococcus aureus dan diinkubasi 24 jam pada suhu $37^{\circ} \mathrm{C}$. Setelah inkubasi 24 jam dihitung diameter zona hambat disekitar disk.

\section{Uji Aktivitas Antibakteri dengan Metode Difusi Disk}

Ekstrak etanol bawang dayak dibuat 4 tingkatan konsentrasi yaitu $25 \%, 50 \%, 75 \%$, dan $100 \%$. Masing-masing konsentrasi dimasukkan ke dalam disk kosong sebanyak $10 \mu \mathrm{L}$. Kemudian disk ditempelkan pada media $\mathrm{MH}$ padat yang telah diinokulasi 200 $\mu \mathrm{L}$ kultur bakteri Staphylococcus aureus konsentrasi $0,5 \times 10^{8}$ CFU per $\mathrm{mL}$ dan diinkubasi 24 jam pada suhu $37^{\circ} \mathrm{C}$. Setelah inkubasi 24 jam dihitung diameter zona hambat disekitar disk.

\section{Analisis Hasil}

Hasil pengecatan Gram menunjukkan bakteri berwarna ungu dan berbentuk kokus. Hasil uji identifikasi Gram manitol bakteri yang mampu memfermentasi manitol tampak sebagai koloni berwarna kuning dengan warna kuning pada media. Hasil penilaian sensitivitas Staphylococcus aureus terhadap antibiotik berdasarkan pengukuran diameter zona hambat yang mengacu berdasarkan panduan CSLI (Clinical Laborator Standard Institute). Pada metode difusi disk, ekstrak yang memiliki aktivitas antibakteri menghasilkan zona hambat.

\section{HASIL DAN PEMBAHASAN}

Ekstraksi merupakan suatu cara untuk memisahkan senyawa dari campurannya mengunakan pelarut tertentu dengan prinsip perbedaan kelarutan. Metode ekstraksi yang digunakan adalah maserasi. Maserasi 
dilakukan dengan merendam simplisia dengan pelarutnya yang kemudian didiamkan. Metode maserasi merupakan metode ekstraksi dingin yang dalam prosesnya tidak memerlukan pemanasan, sehingga dapat menjaga aktivitas dari senyawa aktifnya. Pelarut yang digunakan untuk mengekstrasi bawang dayak adalah etanol $96 \%$.

Setelah proses maserasi selama 3 hari, komponen cairan dipisahkan dari komponen padatan dengan menggunakan penyaring Buchner yang kemudian dilakukan pemekatan ekstrak dengan alat rotary evaporator. Hal ini bertujuan untuk memisahkan ekstrak dengan komponen pelarutnya yang dapat mempengaruhi aktivitas zat aktif dari ekstrak yang diperoleh. Ekstrak yang telah dipekatkan dipanaskan diatas penangas air agar sisa pelarut dalam ekstrak menguap. Hasil ekstraksi didapatkan ekstrak kental bawang dayak 2,85 gram dengan rendemen sebesar 2,85\%. Dari penelitian sebelumnya, ekstrak bawang dayak dibuat dengan menyari 250 gram serbuk bawang dayak dengan pelarut etanol 96\% sebanyak 2 liter didapatkan ekstrak kental sebanyak 12,01 gram dengan rendemen sebesar 4,8\% (Nuur, 2018).

Menurut penelitian yang dilakukan oleh Sa'adah (2017), terdapat perbedaan yang signifikan kandungan flavonoid dalam ekstrak bawang dayak yang diekstraksi dengan metode maserasi dan metode sokhletasi. Hasil penelitian tersebut menyatakan bahwa kandungan flavonoid yang diekstraksi dengan metode maserasi lebih banyak daripada metode sokhletasi. Metode maserasi merupakan metode yang tepat untuk mendapatkan senyawa flavonoid dalam bawang dayak. Flavonoid berfungsi sebagai antioksidan dan antibakteri.

Metode Gram merupakan salah satu teknik yang digunakan untuk mengidentifikasi bakteri dengan larutan zat pewarna kristal violet, larutan yodium, larutan alkohol dan zat warna safranin. Berdasarkan pengecatan Gram, bakteri dapat dibedakan menjadi bakteri Gram positif dan bakteri Gram negatif. Di bawah mikroskop bakteri Gram positif akan tampak bewarna ungu-violet sedangkan Gram negatif akan terlihat bewarna merah. Teknik pewarnaan Gram didasarkan atas perbedaan struktur dinding sel kedua jenis bakteri. Dinding sel bakteri Gram positif hanya terdiri dari satu lapisan tebal yang tersusun dari satu jenis molekul saja. Sementara itu, Gram negatif memiliki dua lapis dinding sel, yaitu lapisan peptidoglikan yang relatif lebih tipis dan membran luar.

Pada penelitian ini hasil pengecatan Gram bakteri berwarna ungu (Gambar 1). Hal ini menunjukkan bahwa bakteri Staphylococcus adalah bakteri Gram positif. Pada pemeriksaan mikroskopis bentuk bakteri tidak terlihat jelas. Stapylococcus merupakan bakteri Gram positif yang berbentuk kokus terdiri atas empat atau delapan kokus menyerupai anggur (Jawetz et al, 2001).

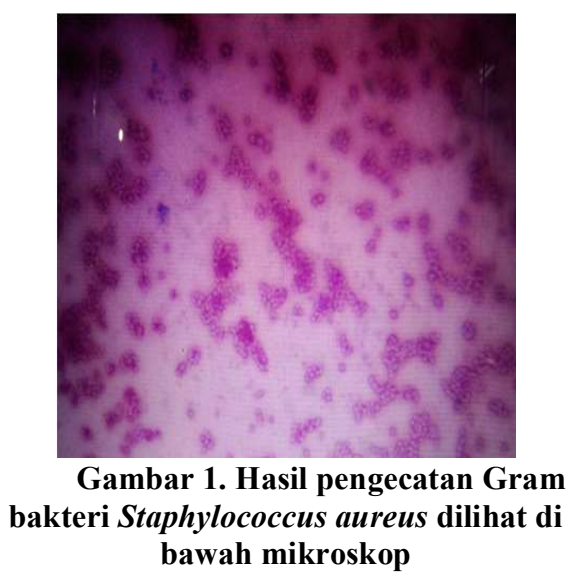

Manitol salt agar (MSA) merupakan media pertumbuhan khusus bakteri halophiles dan dapat membedakan staphylococcus pathogen dan nonpathogenic. Uji manitol didasarkan pada produk limbah yang dihasilkan bakteri, metabolit asam organik, mengubah indikator $\mathrm{pH}$ di media MSA dari merah menjadi kuning cerah. Staphylococcus pathogen, seperti Staphylococcus aureus adalah fementor manitol. Hasil uji identifikasi manitol menunjukkan bakteri yang mampu 
Tabel 1. Hasil uji sensitivitas antibiotik terhadap bakteri Staphylococcus aureus

\begin{tabular}{lcccc}
\hline \multirow{2}{*}{ Antibiotik } & \multicolumn{4}{c}{ Diameter zona hambat (mm) } \\
\cline { 2 - 4 } & \multicolumn{3}{c}{ Literatur CLSI 2016* } & \multirow{2}{*}{ Hasil Penelitian } \\
\cline { 2 - 4 } & $\mathrm{S}$ & $\mathrm{I}$ & $\mathbf{R}$ & \\
\hline Sefoksitin $30 \mu \mathrm{g}$ & $\geq 22$ & - & $\leq 21$ & 23,5 \\
Vankomisin $30 \mu \mathrm{g}$ & $\geq 17$ & $15-16$ & $\leq 14$ & 17 \\
Linezolid $30 \mu \mathrm{g}$ & $\geq 21$ & - & $\leq 20$ & 27,5 \\
\hline
\end{tabular}

*Keterangan: $\mathrm{S}=$ sensitif, $\mathrm{I}=$ intermediet, $\mathrm{R}=$ resisten.

memfermentasi manitol tampak sebagai koloni berwarna kuning dengan warna kuning pada media (Gambar 2). Hal ini menunjukkan bahwa bakteri tersebut merupakan Staphylococcus aureus.

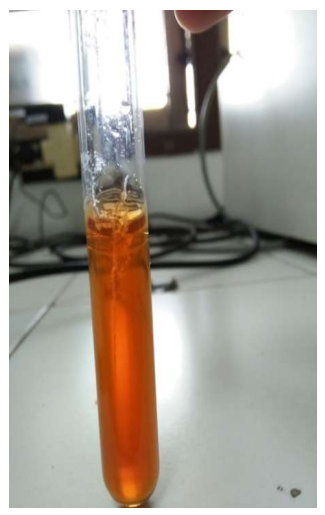

Gambar 2. Identifikasi manitol bakteri $S$. aureus pada media Manitol Salt Agar

Uji sensitivitas Staphylococcus aureus terhadap antibiotik dinilai berdasarkan pengukuran diameter zona hambat yang mengacu pada panduan CLSI (Clinical Laborator Standard Institute). Antibiotik yang digunakan untuk uji sensitivitas bakteri $S$. aureus yaitu vankomisin, sefoksitin, dan linezolid (Gambar 3). Hasil pengukuran diameter zona hambat ketiga antibiotik menunjukkan besar zona hambat terhadap bakteri Staphylococcus aureus masingmasing antibiotik berbeda-beda. S. aureus dinyatakan sensitif terhadap sefoksitin $30 \mu \mathrm{g}$ jika diameter zona hambat $\geq 22 \mathrm{~mm}$ dan resisten jika $\leq 21 \mathrm{~mm}$.

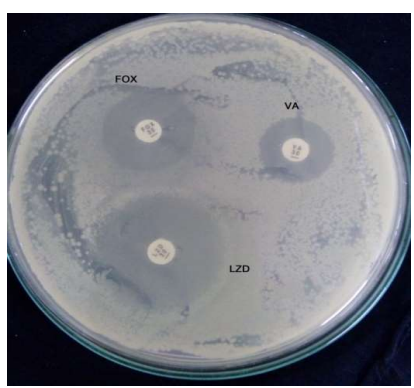

Keterangan:

FOX $=$ Sefoksitin $30 \mu \mathrm{g}$

$\mathrm{VA}=$ Vankomisin $30 \mu \mathrm{g}$

LZD $=$ Linezolid $30 \mu \mathrm{g}$

Gambar 3. Uji sensitivitas antibiotik terhadap S. aureus dengan metode difusi disk pada media Mueller Hinton

Dari hasil penelitian, diameter zona hambat sefoksitin yang terbentuk $23,5 \mathrm{~mm}$. Staphylococcus aureus dinyatakan sensitif terhadap vankomisin $30 \mu \mathrm{g}$ jika diameter zona hambat $\geq 17 \mathrm{~mm}$, intermediet jika $15-16 \mathrm{~mm}$ dan resisten jika $\leq 21 \mathrm{~mm}$. Hasil penelitian diameter zona hambat vankomisin yang terbentuk $17 \mathrm{~mm}$. Staphylococcus aureus dinyatakan sensitif terhadap linezolid $30 \mu \mathrm{g}$ jika diameter zona hambat $\geq 21 \mathrm{~mm}$ dan resisten jika $\leq 20 \mathrm{~mm}$. Hasil penelitian, diameter zona hambat linezolid yang terbentuk 27,5 mm. Dari hasil yang 


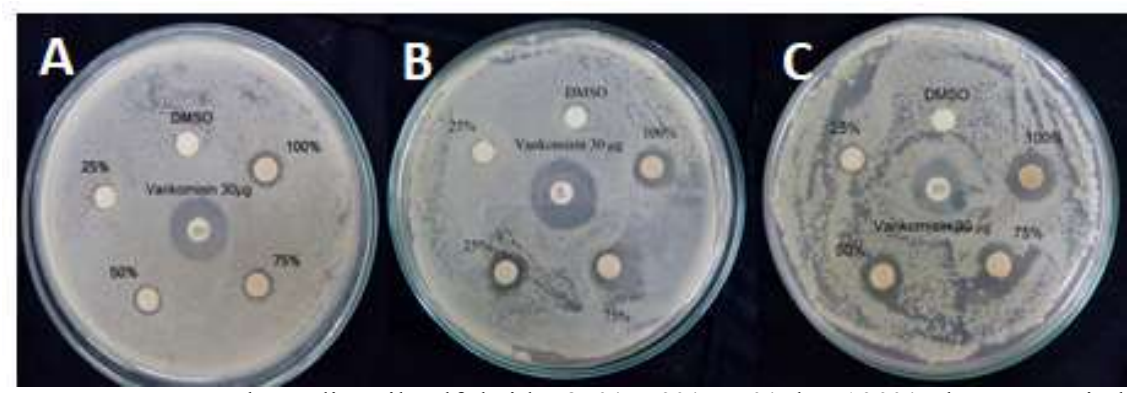

Keterangan: $\mathrm{DMSO}=$ Pelarut dimetil sulfoksida, 25\%; 50\%; 75\% dan 100\%= konsentrasi ekstrak.

Gambar 4. Uji aktivitas antibakteri ekstrak etanol bawang dayak terhadap bakteri Staphylococcus aureus dengan metode difusi disk pada media Mueller Hinton dengan 3 kali replikasi (A, B, dan C)

Tabel 2. Hasil uji aktivitas antibakteri ekstrak terhadap bakteri S.aureus

\begin{tabular}{lccccc}
\hline & \multicolumn{4}{c}{ Diameter zona hambat (mm) } \\
\cline { 2 - 6 } & Uji 1 & Uji 2 & Uji 3 & \multicolumn{2}{c}{ Rata-rata \pm SD } \\
\hline Kontrol pelarut (DMSO) & 8 & 8 & 8 & 8,00 & $\pm 0,00$ \\
Kontrol positif (Vankomisin 30 $\mu \mathrm{g})$ & 15,5 & 20 & 18 & 17,83 & $\pm 2,25$ \\
Ekstrak 25\% & 8,5 & 8 & 8 & 8,17 & $\pm 0,29$ \\
Ekstrak 50\% & 11,5 & 11,5 & 9 & 10,67 & $\pm 1,44$ \\
Ekstrak 75\% & 12 & 10 & 9 & 10,33 & $\pm 1,53$ \\
Ekstrak 100\% & 13,5 & 13 & 10,5 & 12,33 & $\pm 1,61$ \\
\hline
\end{tabular}

Keterangan: diameter zona hambat termasuk diameter disk $(8 \mathrm{~mm})$.

didapatkan maka Staphylococcus aureus bersifat sensitif terhadap antibiotik sefoksistin, vankomisin dan linezolid (Tabel $1)$.

Pada metode difusi disk, ekstrak yang memiliki aktivitas antibakteri menghasilkan zona hambat. Metode difusi disk digunakan untuk menentukan aktivitas antibakteri dengan meletakkan disk berisi agen antibakteri pada media agar yang telah diinokulasi bakteri. Area jernih mengindikasikan adanya hambatan pertumbuhan bakteri karena adanya agen antibkteri pada permukaan agar (Pratiwi, 2008).

Dalam penelitian ini, ekstrak etanol bawang dayak dibuat tingkatan konsentrasi untuk mengetahui pengaruh konsentrasi terhadap zona hambat yang terbetuk. Pembuatan seri konsentrasi menggunakan pelarut DMSO (Dimetil Sulfoksida). DMSO merupakan pelarut organik yang tidak bersifat bakterisida sehingga tidak akan mempengaruhi zona hambat dalam uji aktivitas antibakteri ekstrak etanol bawang dayak.

Ekstrak etanol bawang dayak memiliki aktivitas antibakteri terhadap bakteri $S$. aureus. Hal ini dapat dilihat dari terbentuknya zona hambat pada disk berisi ekstrak yang telah diuji terhadap bakteri S. aureus. Ekstrak etanol bawang dayak menghasilkan zona hambat yang berbeda-beda dari masingmasing konsentrasi (Gambar 4). Diameter rata-rata zona hambat yang terbentuk dari 3 kali uji masing-masing konsentrasi $25 \%$ yaitu $8,17 \pm 0,29 \mathrm{~mm}$, konsentrasi $50 \%$ yaitu 10,67 $\pm 1,44 \mathrm{~mm}$, konsentrasi $75 \%$ yaitu $10,33 \pm$ $1,53 \mathrm{~mm}$, dan konsentrasi $100 \%$ yaitu 12,33 \pm 1,61 mm (Tabel 2). Dari keempat seri konsentrasi hasilnya berbeda tetapi tidak signifikan. 
Jika dibandingkan dengan penelitian sebelumnya, diameter zona hambat ekstrak penelitian ini hasilnya lebih kecil jika dibandingkan dengan penelitian sebelumnya. Hasil penelitian sebelumnya pada konsentrasi $25 \%, 50 \%, 75 \%, 100 \%$ rata-rata diameter zona hambat berturut-turut sebesar 18,32 ; $18,58 \mathrm{~mm} ; 19,47 \mathrm{~mm}$; dan 20,58 $\mathrm{mm}$ (Giardani, 2017). Perbedaan ini dapat disebabkan dari bentuk bawang dayak yang digunakaan. Pada penelitian sebelumnya menggunakan bawang dayak segar sedangkan pada penelitian ini menggunakan serbuk bawang dayak dari distributor. Peneliti tidak mengetahui proses pembuatan serbuk yang kemungkinan prosesnya mempengaruhi jumlah senyawa aktif antibakteri dari bawang dayak. Selain itu umur bawang dayak saat dipanen juga dapat mempengaruhi perbedaan hasil.

Jika dibandingkan dengan kontrol positif antibiotik vankomisin $30 \mu \mathrm{g}$ diameter zona hambat ekstrak juga lebih kecil. Vankomisin $30 \mu \mathrm{g}$ menghasilkan diameter zona hambat rata-rata 17,83 $\pm 2,25 \mathrm{~mm}$. Mekanisme kerja dari vankomisin membunuh bakteri dengan menghambat sintesis dinding sel bakteri (Anaizi, 2002). Pada kontrol pelarut yaitu disk yang berisi DMSO tidak menghasilkan zona hambat atau diameter zona hambat sama dengan diameter disk. Hal ini menunjukkan bahwa DMSO tidak memiliki aktivitas antibakteri dan tidak mempengaruhi aktivitas antibakteri dari ekstrak etanol bawang dayak.
Pada penelitian ini tidak dilakukan penapisan fitokimia untuk mengidentifikasi kandungan senyawa pada ekstrak etanol bawang dayak. Sehingga tidak dapat diketahui apa saja senyawa aktif yang memiliki aktivitas antibakteri serta jumlah senyawa aktif yang terkandung dalam ekstrak etanol bawang dayak. Menurut penelitian yang dilakukan oleh Puspadewi (2013), hasil penapisan fitokimia ekstrak etanol bawang dayak dengan pelarut etanol $96 \%$ didapatkan hasil senyawa yang terkandung dalam ekstrak etanol bawang dayak yaitu: senyawa alkaloid, flavonoid, kuinon, polifenol, steroid/triterpenoid, monoterpenoid/ seskuiterpen, dan tanin. Data tersebut didukung oleh pustaka dari Departemen Kesehatan Republik Indonesia (2001), yaitu hasil identifikasi dan pustaka menunjukkan persamaan kandungan dalam ekstrak etanol bawang dayak. Senyawa yang diduga memiliki aktivitas antimikroba yaitu: flavonoid, polifenol dan terpen.

\section{KESIMPULAN}

Ekstrak etanol bawang dayak memiliki aktivitas antibakteri terhadap bakteri Staphylococcus aureus. Diameter rata-rata zona hambat yang terbentuk masing-masing konsentrasi $25 \%$ yaitu $8,17 \pm 0,29 \mathrm{~mm}$, konsentrasi $50 \%$ yaitu $10,67 \pm 1,44 \mathrm{~mm}$, konsentrasi $75 \%$ yaitu $10,33 \pm 1,53 \mathrm{~mm}$, dan konsentrasi $100 \%$ yaitu $12,33 \pm 1,61 \mathrm{~mm}$. Hasil berbeda tetapi tidak signifikan.

\section{DAFTAR PUSTAKA}

Alves T.M.A., Helmut K. dan Carlos L.Z., 2003, Eleutherinone a Novel Fungitoxic Naphtoquinone from Eleutrine bulbosa (Iridiceae), Mem.Inst. Oswaldo Cruz. Rio de Janeiro, Vol 98(5): 709-712.

Departemen Kesehatan R.I., 2001, Inventaris Tanaman Obat Indonesia (I), Jilid 2, Departemen Kesehatan dan Kesejahteraan Sosial Republik Indonesia, Jakarta.

Febrinda A.E., 2013, Potensi Antioksidan dan Antidiabetik Ekstrak Air dan Etanol Umbi Bawang Dayak (Eleutherine palmifolia) Secara In Vitro dan In Vitro [Disersasi], Sekolah Pascasarjana IPB, Bogor.

Galingging R.Y., 2009, Bawang Dayak (Eleutherine palmifolia (L.) Merr) Sebagai Tanaman Obat Multifungsi, Warta Penelitian dan Pengembangan, Vol 15, No 3, Hal 2-4. 
Gandjar I.G., dan Rohman A., 2007, Kimia Farmasi Analisis, Pustaka Pelajar, Yogyakarta.

Giardani R.N., 2017, Perbandingan Daya Hambat Ekstrak Etanol Bawang Dayak (Eleutherine Palmifolia L.) Dengan Bawang Merah (Allium Ascalonicum L.) Terhadap Bakteri Staphylococcus Aureus, Karya Tulis Ilmiah, Stikes Nasional, Surakarta.

Hidayah A., Mulkiya K., dan Purwanti L., 2015, Uji Efektivitas Antioksidan Bawang Dayak (Eleutherine bulbosa L.), Laporan Penelitian, UNISBA, Jakarta.

Jawetz M.G.E., and Adelberg C.A., 2001, Mikrobiologi Kedokteran Edisi I, Bagian Mikrobiologi Fakultas Kedokteran Universitas Airlangga, Surabaya.

Jawetz M.G.E. and Adelberg C.A. 2008. Mikrobiologi Kedokteran. Jakarta: Penerbit Buku Kedokteran EGC.

Kusuma S.A.F., 2009, Uji Biokimia Bakteri, Karya Ilmiah, Universitas Padjajaran, Bandung.

Nuur A.P.E., dan Haryoto, 2018, Uji Aktivitas Antikanker Kombinasi Eksrak Etanol Umbi Bawang Dayak (Eleutherine Amricana Merr.) dan Biji Sirsak (Annona Muricata) Dengan Metroteksat Terhadap Sel T47d, Skripsi, Univesitas Muhammadiyah Surakarta, Surakarta.

Pratiwi A.T., 2008, Mikrobiologi Farmasi, Penerbit Erlangga, Jakarta.

Puspadewi R., Adirestuti P., dan Menawati, R., 2013, Khasiat Umbi Bawang Dayak (Eleutherine palmifolia (L.) Merr) Sebagai Herbal Antimikroba Kulit, Kartika Jurnal Ilmiah Farmasi, 1 (1), 31-37.

Ryan K.J., Champoux, Falkow, Plonde, Drew, Neidhardt, and Roy, 1994, Medical Microbiology An Introduction to Infectious Diseases $3 \mathrm{rd}$ ed, Appleton\&Lange, Connecticut.

Sa'adah, H., 2017, Pengaruh Metode Ekstraksi Terhadap Kadar Flavonoid Ekstrak Etanol Umbi Bawang Dayak (Eleutherine palifollia (L.) Merr) Dengan Metode Spektrofotometri, Journal, Akademi Farmasi, Samarinda. 